\title{
LIOTIA ORNATA N. SP. (MOLLUSCA, GASTROPODA) FROM BADENIAN OF BOROD BASIN (NW ROMANIA)
}

\begin{abstract}
MIRELA POPA $^{1}$
ABSTRACT. A new small-sized gastropod species was identified in Badenian deposits (Borod Formation) in the eastern part of Borod Basin (west of Apuseni Mts.), and was described in this study under Liotia ornata n. sp.
\end{abstract}

KEY WORDS: Liotia ornata, New taxa, Gastropoda, Badenian, Borod Basin, Romania.

\section{Introduction and stratigraphical setting}

Neogene deposits from the eastern part of Borod Basin mainly consist of marls and clays, and subordinately of sandstones, microconglomerates, sands, tuffs, and coal. The whole succession was attributed to three lithostratigraphic units: (Popa, 2000): Borod Formation (Eggenburgian-Badenian), Cornițel Formation (Early Sarmatian), and Beznea Formation (Pannonian).

The deposits of Borod Formation outcrop on a limited area in the northeastern part of the basin (north from Borod locality), and were intercepted in boreholes north from Borod valley, between the localities Gheghie (west) and Borod (east). These deposits preserve a rich mollusk fauna. Popa (in Popa \& Chira, 2000) separated three faunal assemblages, based on core samples: PirenellaTheodoxus-Tympanotonos assemblage, Turritella - Anadara assemblage, and Alvania - Ringicula - Pyramidella assemblage. The latter one was identified in the upper part of Borod Formation, and mainly contains small-sized taxa: Obsoletiforma kokkupica (ANDRUSSOV), Loripes dentatus (DEFRANCE), Alveinus nitidus (REUSS), Alvania venus danubiensis COSSMANN \& PEYROT, A. montagui ampulla (EICHWALD), Teinostoma woodi (HOERNES), Bittium reticulatum (COSTA), Cerithiopsis tubercularis astensis COSSMANN, Triphora perversa (LINNE), Piramidella plicosa (BRONN), Odostomia dispar BOETTGER, O. perrara BOETTGER, O. subintermedia (COSSMANN \& PEYROT), Eulimella nitidissima (MONTAGU), E. conulus EICHWALD, Chrysallida interstincta (MONTAGU), C. sacyi (COSSMANN \& PEYROT), Turbonilla scala (EICHWALD), and Ringicula costata (EICHWALD).

Beside these species, which are overspread in the Badenian deposits of Paratethys, also specimens belonging to Liotia genera were identified. Liotia ornata n. sp. identified in boreholes 3163, 3162, 3166, 3154, and 575 (fig. 1).

\footnotetext{
1 "Babeş-Bolyai" University, Department of Geology, Str. Kogălniceanu 1, 3400 Cluj- Napoca, Romania.
} 


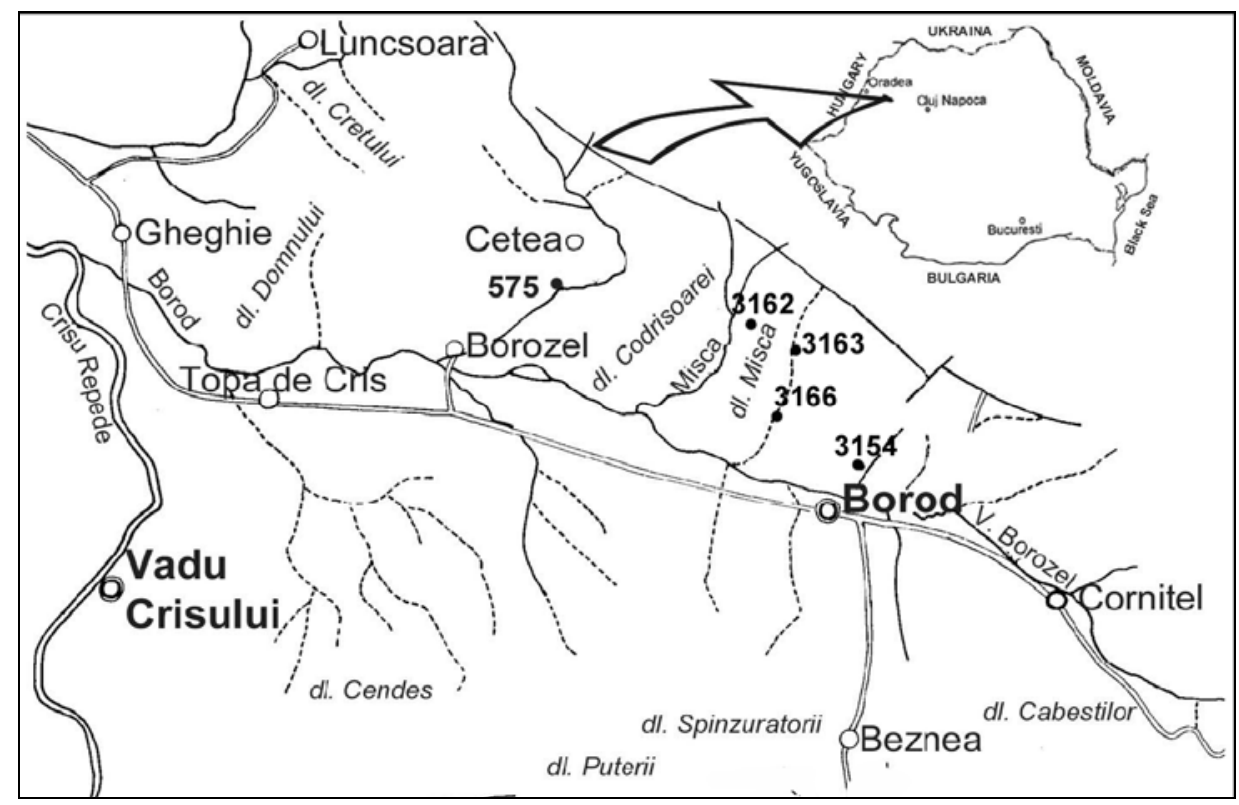

Fig. 1 Location of the studied boreholes

\section{Systematic description}

Class Gastropoda CUVIER, 1797

Order Archaeogastropoda THIELE, 1925

Superfamily Trochacea RAFINESQUE, 1815

Family Liotiidae

Genus Liotia GRAY, 1847

\section{Liotia ornata $\mathrm{n} . \mathbf{s p}$.}

PI. I, PI. II

1990 Architectonica n. sp.-Moisescu, p.178, pl. VIII, fig. 2a-b, 3a-b

Ho l o t y $p$ e: The specimen illustrated in pl.I, fig. 1a,b,c (Inv. MPSUBB 23275H) $P$ a r a ty $p$ e $s$ : Inv. MPSUBB 23276-23282 (PI. I, Fig. 2a,b,c; PI. II, Fig. 1a,b,c, 2a,b, $3 a, b)$.

All the specimens are deposited in the collection of the Museum of Paleontology- Stratigraphy, Babeş-Bolyai University, Cluj-Napoca (MPSUBB).

D e rivat i o n o m i i s: Latin orno - ornata (perfect participle of the verb orno) $=$ to adorn, to embellish.

Ty p e I o c a l it y: Borod, locality in the eastern part of Borod depression (west of Apuseni Mountains.).

Ty p e l e ve I: Badenian (upper part of Borod Formation). 
D $i$ a $g$ n o s $i$ s: very small-sized shell, planispiral rolled, with the last whorl covering almost the whole shell. Two carinas on the last whorl and ornamentation consisting of axial ribs intersected by fine spiral cords.

$D$ e s c r i p t i o n: very small-sized white, glossy shell, with thickened whorl walls. The protoconch is smooth, and plate, while the spire consists of three fast-growing whorls, the last one almost fully surrounding the whole shell. The suture is poorly marked, being better noticeable due to the undulated carinae.

The last whorl shows two undulated carinae, an upper one, more pronounced, and a lower one. On the external surface of the shell, the whorl ornamentation consists of axial ribs, better visible in the case of the first whorl (19 on the last but one whorl), being intersected by fine spiral, and equidistant cords.

The last whorl is ornamented in the first part by strong ribs, which gradually pass into fine and closely ribs (42-43), intersected by equidistant spiral cords (14). 60-62 equal ribs ornament the almost planar lateral area between the two carinae; the space in-between the ribs are smaller than the surface of the ribs, being intersected by fine spiral, equidistant cords (25).

The basal surface of the shell is ornamented with 39-40 radial, slightly undulated ribs that cover the surface between the umbilicus and the lower carina. 15 spiral cords intersect them.

The umbilicus is narrow and deep, the cords gradually thinning towards it until they disappear. The aperture has an almost circular outline, being slightly angular at the upper side, at the contact with the basis of the spire. The peristome is continuous, with a polygonal outline towards the exterior due to the carinae. The internal wall of the shell is pearly.

I $n$ tras pe c if i c variability: The analysis of the 16 specimens (among which 3 represent young specimens) shows little variation of the number of ornamentation elements (cords and ribs).

M a $t$ e ri a l: 16 shells were collected, from the following borehole: 8 from borehole 3163, 3 from borehole 3154, 2 from borehole 575 and one from each boreholes 3162, and 3166. The size of the completely preserved shells is given in the table:

\begin{tabular}{|l|c|l|l|}
\hline $\begin{array}{c}\text { Inv. Number } \\
\text { MPSUBB }\end{array}$ & $\begin{array}{c}\text { Location } \\
\text { (Boreholes) }\end{array}$ & Height & Width \\
\hline $23275 \mathrm{H}$ & $3166 / 158.7 \mathrm{~m}$ (holotype) & $1.30 \mathrm{~mm}$ & $2.80 \mathrm{~mm}$ \\
\hline 23275 & $3166 / 158.7 \mathrm{~m}$ & $0.70 \mathrm{~mm}$ & $1.25 \mathrm{~mm}$ \\
\hline 23276 & $3162 / 289.2 \mathrm{~m}$ & $1.55 \mathrm{~mm}$ & $3.00 \mathrm{~mm}$ \\
\hline 23277 & $3163 / 189.1 \mathrm{~m}$ & $1.50 \mathrm{~mm}$ & $2.90 \mathrm{~mm}$ \\
\hline 23278 & $3154 / 40.5 \mathrm{~m}$ & $1.25 \mathrm{~mm}$ & $2.40 \mathrm{~mm}$ \\
\hline 23279 & $3163 / 267.5 \mathrm{~m}$ & $1.00 \mathrm{~mm}$ & $2.00 \mathrm{~mm}$ \\
\hline
\end{tabular}

$R$ e $m$ a $r k s$ : The material collected from the boreholes samples in the eastern part of Borod Basin resemble Liotia calculiformis BOETTGER described from Coştei in 1906 (p. 188) and illustrated by Zilch (1934, pl.3, fig. 51), as far as the general shape and partly the ornamentation are concerned. Liotia calculiformis shows fewer and poorly defined ribs on the basal side, while at the upper side it has seven well-developed tubercles, giving a general undulated outline to the upper carina, as Boettger mentioned in his diagnosis. The author did not describe the spiral ornamentation on the surface of the shell, which in fact is missing also in the 
case of the specimen illustrated by Zilch. But this feature is present on the specimens of Liotia ornata n. sp. collected from Borod Basin.

Liotia calculiformis was also identified in Şimleu Basin (Tusa) by Nicorici (1974), in Upper Badenian deposits; the specimen is included in the collection of the Paleontology-Stratigraphy Museum, Babeş-Bolyai University, Cluj-Napoca. The form collected from Tusa preserves all the typical features for Liotia calculiformis described by Boettger; more, a fine ornamentation with spiral cords can be seen, the specimen being better preserved than that from Coştei.

In conclusion, the specimens collected from the eastern Borod Basin differ from Liotia calculiformis BOETTGER identified at Coştei and Tusa as far as the ornamentation is concerned. The ribs are less pronounced and more numerous, while the fine spiral cords cover the whole area of the shell. Also, the tubercles are missing from the upper side.

Strat igraph ic rang e: Liotia ornata n. sp. was identified only in the upper part of Borod Formation, besides other well-spread taxa in the Badenian deposits of Central Paratethys.

\section{REFERENCES}

Boettger, O., 1901-1907: Zur Kenntnis der Fauna der mittelmiocänen Schichten von Kostej im Krassó - Szörényer Komitat, Verhand. und Mitt. des Siebenbürg für Naturw. zu Hermannstadt, 51, 54, 55, Sibiu

Nicorici, E., 1974: Minutinele badenian-superioare de la Tusa (Bazinul Şimleu), D. S. (Paleont.), LX, (1972-1973), 3, p.94-114, 6 pl., Bucureşti.

Popa, M., Chira, C., 2000: Miocene mollusks and calcareous nannoplankton assemblages from the Borod Formation (Borod Basin, Romania), Acta Palaeontologica Romaniae, 2 (1999), p. 397-406, 2 fig., 1 tab., 4 pl., Cluj-Napoca.

Popa, M., 2000: Lithostratigraphy of the Miocene deposits in the eastern part of Borod Basin (NW of Romania). Studia Univ. Babeş-Bolyai, XLV, 2, p. 93-103, 5fig., Cluj-Napoca.

Zilch, A., 1934: Zur Fauna des Mittel - Miocäns von Kostej (Banat) Typus-Bestimmung und Tafeln zu O. Boettger's Bearbeitungen, Senckbergiana, 16, 4/6, p.193-302, 22 pl., Frankfurt a Main.

Plate I

\section{PLATES}

Fig. 1a, b, c. Liotia ornata n. sp. - holotype F.3166 / 158.70 m Inv.MPSUBB $23275 \mathrm{H}--\times 15.5$

Plate II

Fig 2 a, b, c. Liotia ornata n. sp. - F. 3162 / 289.20 m

$$
\text { Inv.MPSUBB } 23276 \quad \times 15
$$

Fig 1 a, b, c. Liotia ornata n. sp. - F. 3163 / 189.10 m

Fig 2 a, b. Liotia ornata n. sp. - F.3154 / 40.50 m Inv.MPSUBB $23277 \quad \times 10$

Fig 3 a, b. Liotia ornata n. sp. -- F. 3163 / 265.00 m nv.MPSUBB $23278 \quad \times 15$

Fig $4 \quad$ Liotia ornata n. sp.- juvenil specimen F. $3166 / 158.70 \mathrm{~m}$ Inv.MPSUBB $23275 \quad \times 23$ 


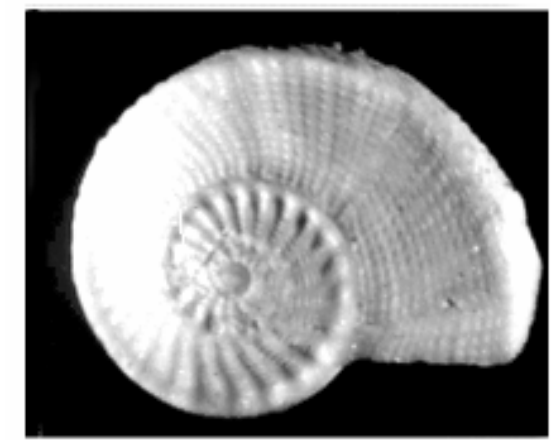

1a

PLATE I

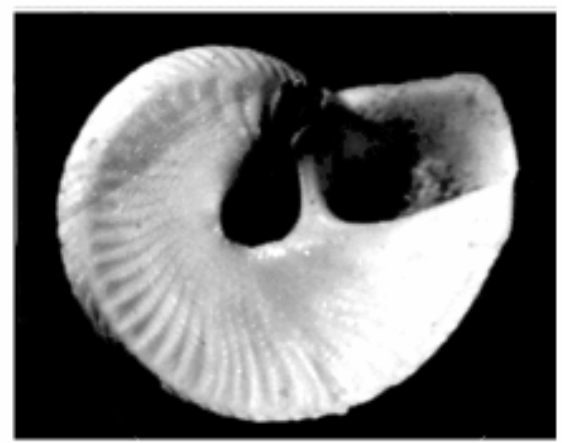

$1 \mathrm{~b}$

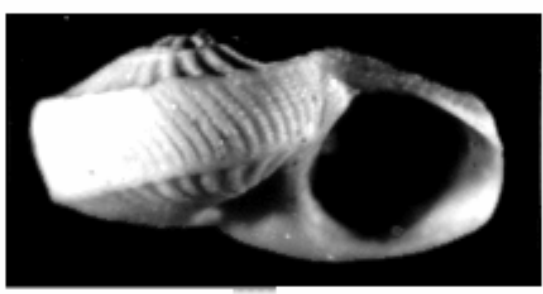

$1 \mathrm{c}$

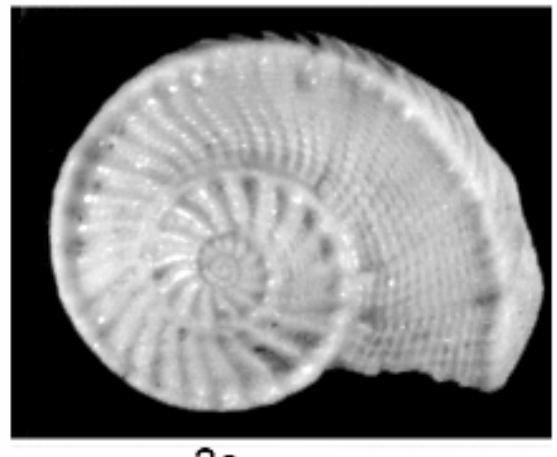

$2 a$

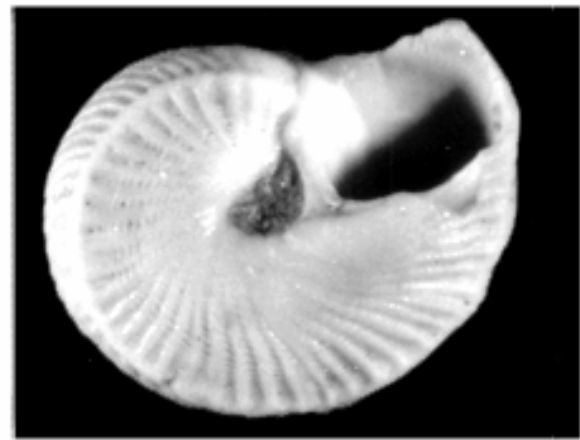

$2 \mathrm{~b}$

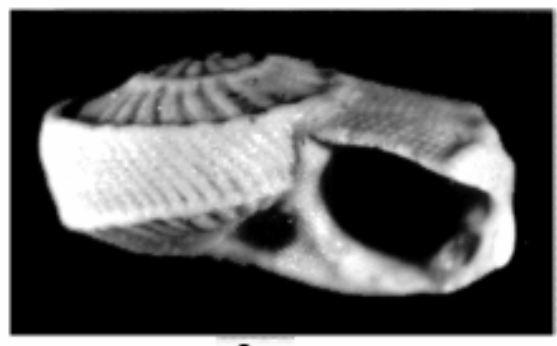

2c 


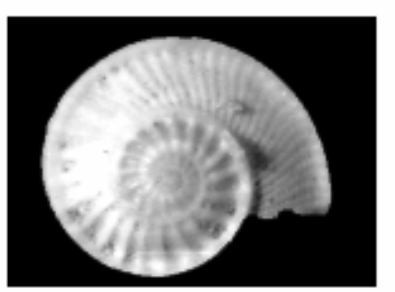

$1 a$

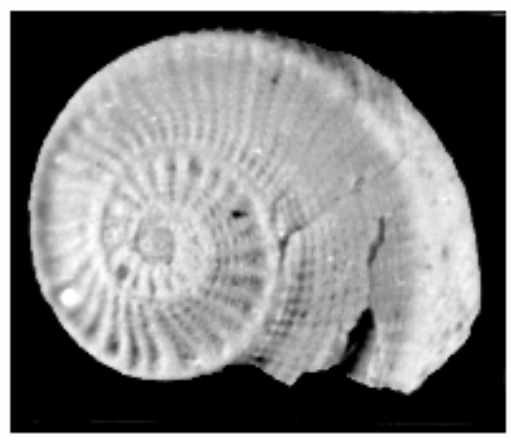

$2 a$

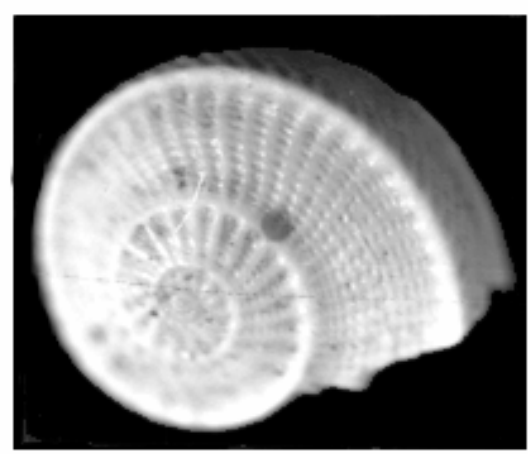

$3 a$

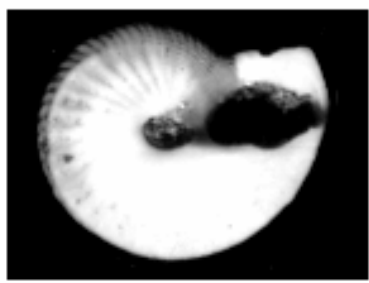

1b

PLATE ॥

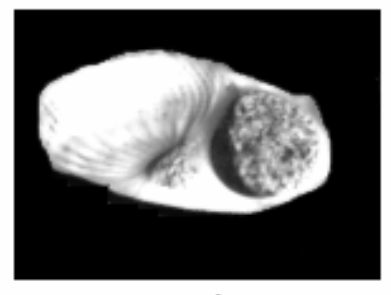

$1 \mathrm{c}$

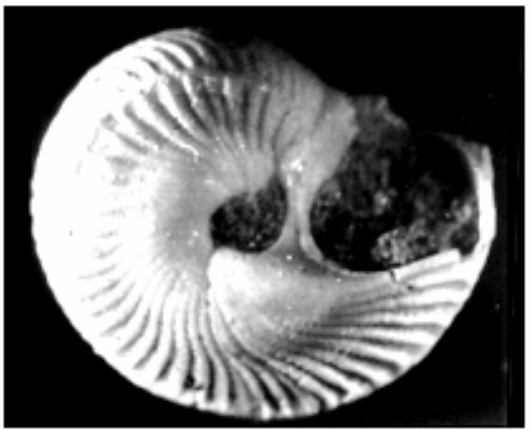

$2 b$

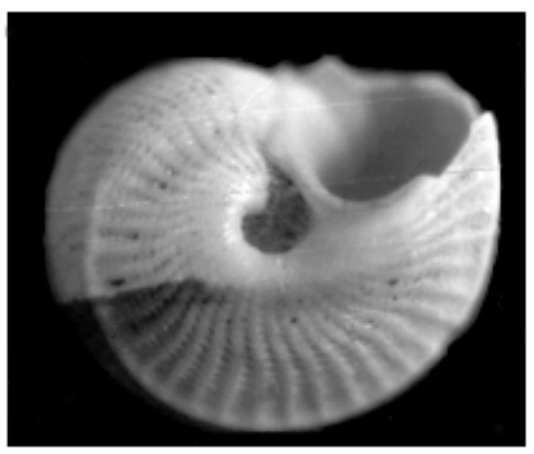

$3 b$

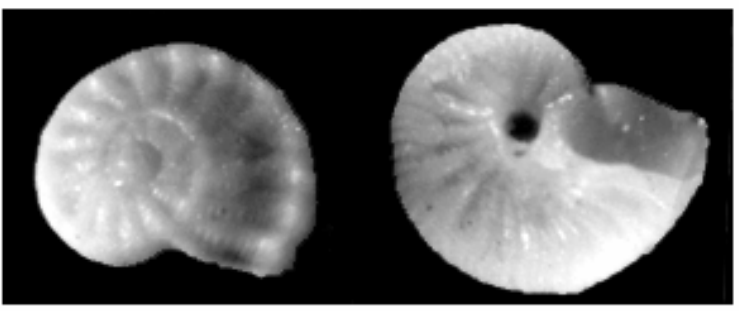

4 